Canadian Studies in Population, Vol. 35.1, 2008, pp. 187-205

\title{
Is Separation still an Important Component of Marital Dissolution?
}

\author{
Wayne W. McVey, Jr. \\ Professor Emeritus \\ Department of Sociology \\ University of Alberta \\ Edmonton, Alberta \\ wmcvey@ualberta.ca
}

\begin{abstract}
This research examines the diversification and changes in the Canadian family form over the past 25 years. While the husband-wife family has declined over this time period, it still remains the dominant family form. Statistics Canada census statistics allows for the examination of new family forms since 1981, as the common-law partnership and the now married have been distinguished within the husband-wife family category. With the introduction of the 1968 and 1985 Divorce Acts, separation became a major ground for divorce in Canada. Marital breakdown should be measured by the incidence of both divorce and separation. The popularity of cohabitation further clouds the measuring of total partnership breakdown since separation of cohabiting partners is not recorded. This research focuses on the change in marital separation and the increase in cohabitation since 1981. Marital separation has declined in its contribution to total marital dissolution since 1985.
\end{abstract}

Key Words: Separation, marital breakdown, cohabitation, divorce 
Wayne W. McVey, Jr.

\section{Résumé}

Cet article examine la diversification et les changements de la structure de la famille canadienne au cours des 25 années dernières. Bien que le nombre de familles époux-épouse a subi en déclin pendant cette période, celle-ci reste toujours la structure de famille majoritaire. Les données des recensements de Statistique Canada nous permettent d'examiner les nouveaux modèles de familles depuis 1981, puisque les unions libres et les actuellement mariés ont été séparer au sein de la catégorie époux-épouse. Avec l'introduction des lois sur le divorce de 1968 et 1985, la séparation est devenue un motif de divorce majeur au Canada. Les ruptures conjugales devraient être mesurées par le nombre de divorces et de séparations. La popularité des unions libres rend encore plus confuse l'exact mesure du total des ruptures conjugales puisque la séparation de conjoints de fait n'est pas enregistrée. La présente recherche se centre sur les changement dans les séparations conjugales et la hausse des unions libres depuis 1981. La séparation conjugale en tant que facteur contribuant à la dissolution conjugale est en déclin depuis 1985.

Mots-clés : Séparation, rupture conjugale, union libre, union de fait, divorce

\section{Introduction}

Public concern continues to be expressed over the stability of the Canadian family. Given the emerging diversification of the family form and increasing popularity of common-law partnerships, the "traditional" family continues to be the prevailing choice of Canadians.

As indicated in Table 1, while increasing numerically, the traditional husbandwife family form has declined from 83.1 percent in 1981 to 70.5 percent in 2001. Statistics Canada includes common-law unions along with the now married unions in the total husband-wife family category. Correspondingly, there has been a significant rise in cohabiting partnerships over this same time period - increasing their share of all husband-wife families from 5.6 to 13.8 percent of total families in 2001. Over this twenty-year period, common-law unions increased by 801,800 , husband-wife families increased by 647,060 , and lone-parent families increased 597,180. 


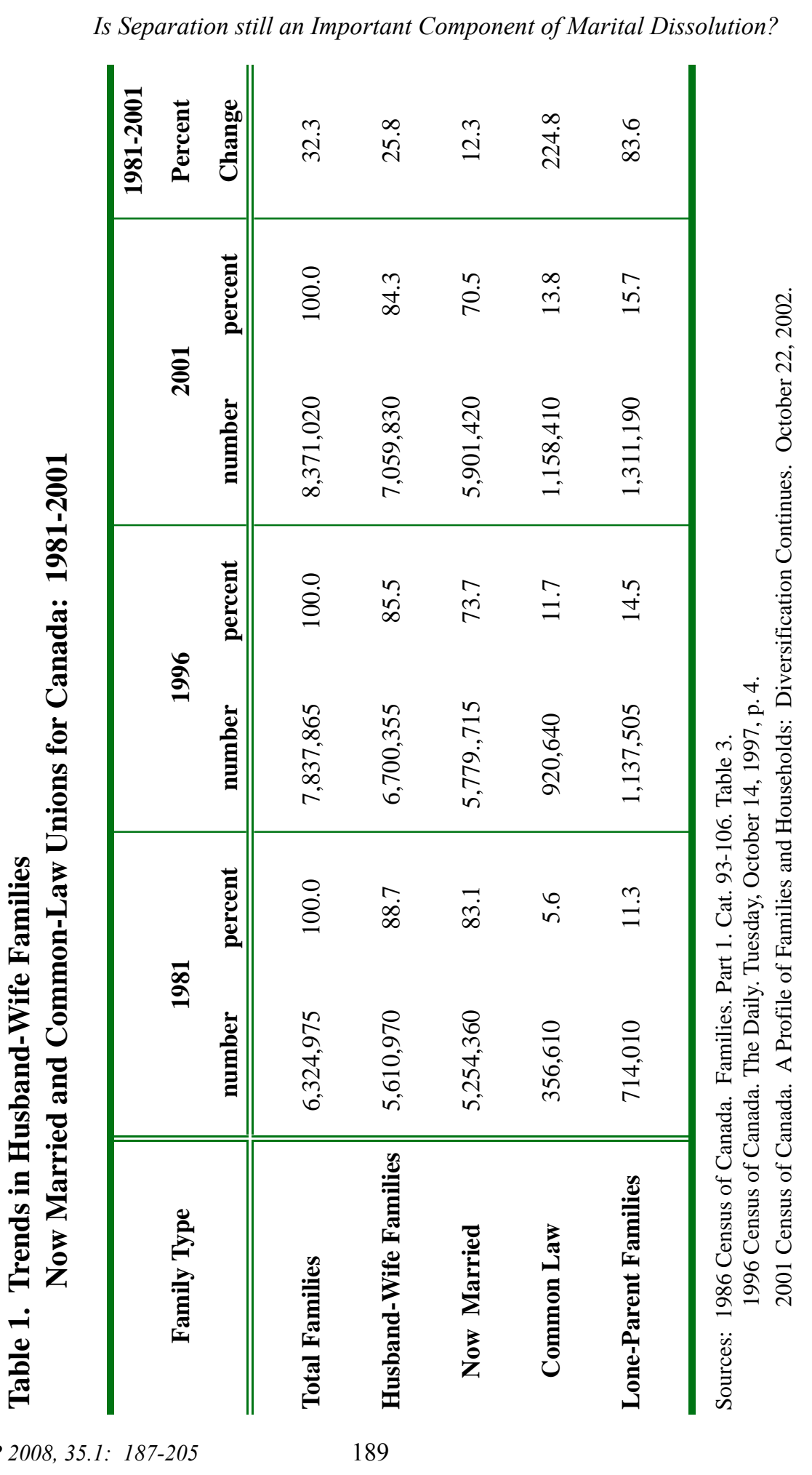


Wayne W. McVey, Jr.

Recent research findings concerning cohabitation in Canada have concluded that cohabitation is increasingly viewed as a viable alternative to the marriage, rather than merely a "staging platform" in preparation for marriage (Dumas and Bélanger, 1997). Earlier findings of the 1984 Family History Survey had concluded that common-law relationships were the predominant choice of younger populations and that cohabitation was generally viewed as a stage preceding marriage - perhaps for many, simply a replacement for the more formal engagement stage.

The formation of cohabiting partnerships clouds the measurement of family and marital dissolution in Canada. While recognizing cohabitation as a family form, this relationship is not a continuously registered or recorded event as is formal marriage. Correspondingly, premarital divorce or the breakdown of commonlaw partnerships is not formally registered. With cohabitation viewed as an alternative to marriage, the measurement of family or marital dissolution utilizing divorce events now becomes tantamount to an under-estimate of family breakdown.

\section{Divorce as an Indicator of Marital Breakdown}

We continue to rely on the measurement of divorce as an indicator of the extent of family breakdown or marital dissolution in Canada. Divorce is the formalized final stage in the total process of marriage breakdown (McVey \& Robinson, 1981). Prior to the 1968 Act, the more restrictive grounds for divorce involved serious marital offenses, such as marital cruelty, marital rape, sodomy, bestiality, homosexuality and adultery. These grounds prevented many couples from formally dissolving their relationship. Many marriages dissolved by taking other options, such as separation, desertion, or simply maintaining an "empty shell" relationship by minimizing communication between partners (Goode, 1964).

With the implementation of the 1968 and 1985 Divorce Acts, separation became an integral initial stage in the divorce process. The 1968 Divorce Act accepted separation as a legitimate ground for divorce. Now one did not have to commit a serious marital offense or commit perjury in court, in order to formally dissolve their marriage. The required period of separation prior to petitioning for formal divorce was three years for the "non-guilty" party and five years for the "guilty" party. The guilty partner was determined in terms of who left "bed and board." The 1985 Divorce Act removed the guilt aspect of divorce and allowed a partner to petition for divorce on the one-year anniversary of separation. In either case, family breakdown would occur at the onset of separation and not divorce. 
Is Separation still an Important Component of Marital Dissolution?

Consequently, with our continued reliance on divorce as the only indicator of marital dissolution, one cannot determine the full nature and extent of marital disruption in Canada. Interfaced between marriage and divorce is the intermediate stage of separation. Accordingly, not all separated individuals finalize their marital breakdown by getting divorced, but those who are divorced have gone through a separation stage. Although, separation is an intermediate stage in the process, those who are separated have already experienced the emotional and physical turmoil of marital breakdown.

While divorce has been continuously monitored and reported by Statistics Canada since 1921, separation is not tracked on a continuous basis Social scientists contributing to our understanding of marital dissolution relied only on divorce as the measurable indicator of family breakdown. Commencing with the 1981 Census of Canada, cohabitation as a distinct relationship status along with husband and wife partnerships was included in the family category for the first time. To complete the picture of partnership dissolution, ideally we should establish monitoring of marital separation, as well as cohabitation separation.

Marital separation is a legal marital status and is recorded in the periodic conduct of the national census. Along with married, divorced, widowed, and single, never married there is the category of legally married, but separated. Prior to the 1976 census, separated status was merged with the married status on the basis that being separated does not legally nullify the marriage. (McVey \& Robinson) It should also be noted that separated status was reported by age in the tabulations from the 1941 Census of Canada. It is now possible to obtain special tabulations from Statistics Canada pertaining to the separated population by age for the census years following 1976. While the problem of timeliness remains an issue, the availability of such a key marital status dimension is essential to the understanding of the marital dissolution of marital partnerships in Canada.

A review of divorce trends reveals the marked increase in Canadian divorces between 1941 and 1946. This rise in divorce occurred during the Second World War and in the immediate period following the cessation of hostilities. The incidence of divorce was extremely low during the period prior to the implementation of the 1968 Divorce Act and the divorce rate increased dramatically following 1968 and again after the 1985 Divorce Act. As can be seen in Figure 1 and Table 2, the divorce rates declined prior the implementation of the 1985 Act as a consequence of separated partners waiting to take advantage of the more equitable mandates of the new divorce legislation. The removal of advocacy or "guilt" from the petitioners, the more equitable 
Wayne W. McVey, Jr.

settlements, the reduction of the waiting period from 3 months to 1 month between Nisei and Absolute decrees - all were factors contributing to the wait for the implementation of the new divorce act.

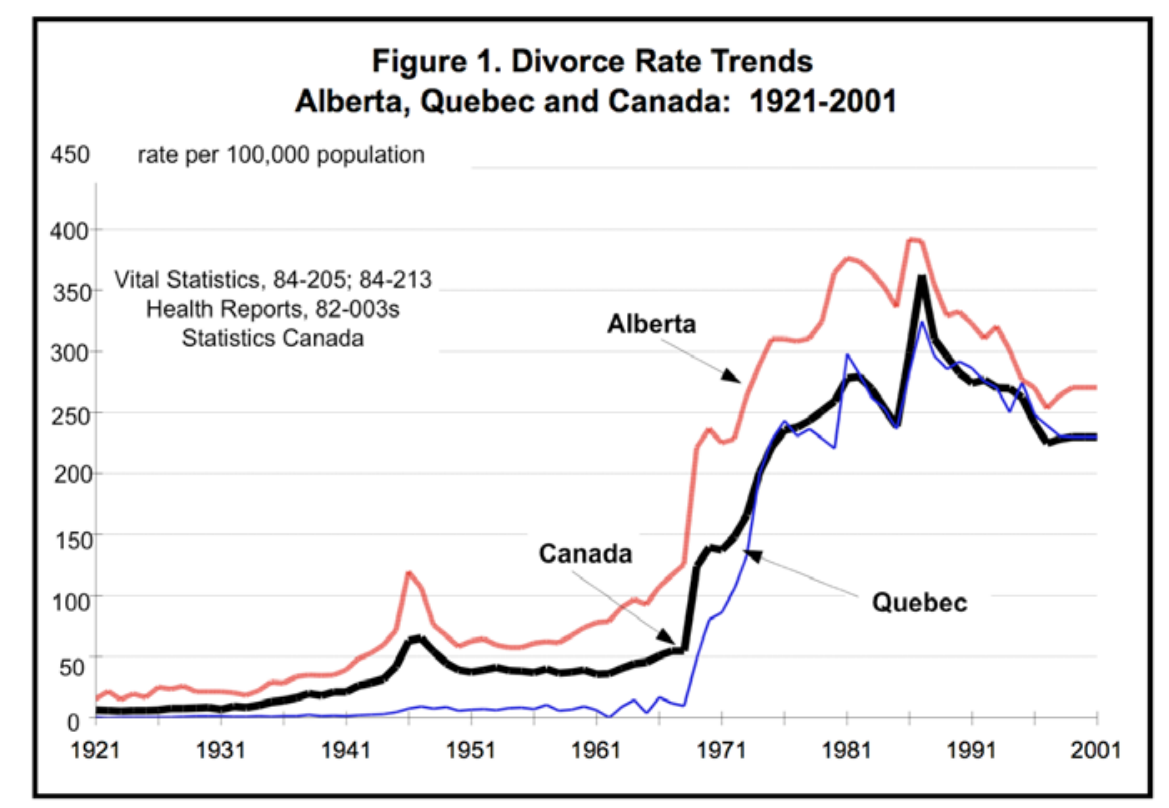

Divorce rate trends weakened following the implementation of the 1985 Divorce Act and have generally declined from a recorded high of 90,985 divorces in 1987 to a low of 71,110 in 2001 . Divorce rates also vary from province to province. The growth provinces of Alberta and British Columbia generally have higher levels of divorces. This is the consequence of the economic attractiveness of these provinces resulting in a higher net migration of younger populations. Correspondingly, the subsequent higher marriage rates contribute to a larger pool of eligibles at risk to marital dissolution.

Higher rates of female labour force participation in these provinces may have contributed to higher incidence of divorce. The advances that women have made in both education and accomplished competitiveness in the labour force have likely resulted in greater independence and financial security on the part of Canadian women. Consequently, transitions from married to the divorced state are made with greater ease and confidence than before (Kalbach \& McVey, 1995; Booth \& White, 1980). 
Is Separation still an Important Component of Marital Dissolution?

Table 2

Divorce Trends for Canada, Selected Years: 1941-2001

\begin{tabular}{|c|c|c|c|c|}
\hline \multirow{2}{*}{ Year } & \multicolumn{2}{|c|}{ Divorces } & \multicolumn{2}{|c|}{ Increase over Previous Year } \\
\hline & Number & Rate & Number & Percent \\
\hline 1941 & 2,462 & 21.4 & & \\
\hline 1946 & 7,757 & 63.1 & & \\
\hline 1951 & 5,270 & 37.6 & & \\
\hline 1956 & 6,002 & 37.3 & & \\
\hline 1961 & 6,563 & 36.0 & & \\
\hline 1966 & 10,239 & 51.2 & & \\
\hline 1968 & 11,343 & 54.8 & 178 & 2.0 \\
\hline 1969 & 26,093 & 124.2 & 14,750 & 130.0 \\
\hline 1970 & 29,775 & 139.8 & 3,682 & 14.0 \\
\hline 1971 & 29,685 & 137.6 & -90 & -0.3 \\
\hline 1976 & 54,207 & 235.8 & 3,596 & 7.0 \\
\hline 1981 & 67,671 & 278.0 & 5,652 & 9.0 \\
\hline 1986 & 78,160 & 298.8 & 16,180 & 26.1 \\
\hline 1987 & 90,985 & 362.3 & 12,825 & 16.4 \\
\hline 1988 & 79,872 & 310.5 & $-11,113$ & -12.2 \\
\hline 1989 & 80,716 & 295.8 & 844 & 1.1 \\
\hline 1990 & 78,152 & 282.3 & $-2,564$ & -3.2 \\
\hline 1991 & 77,031 & 273.9 & $-1,121$ & -1.9 \\
\hline 1992 & 79,034 & 276.9 & 2,003 & 2.6 \\
\hline 1993 & 78,226 & 270.3 & -808 & -1.0 \\
\hline 1994 & $\mathbf{7 8 , 8 8 0}$ & 269.7 & 654 & 0.8 \\
\hline 1995 & 77,636 & 262.2 & $-1,244$ & -1.6 \\
\hline 1996 & 71,528 & 241.1 & $-6,108$ & -7.9 \\
\hline 1997 & 67,408 & 224.7 & $-4,120$ & -5.8 \\
\hline 1998 & 69,088 & 228.4 & 1,680 & 2.5 \\
\hline 1999 & 70,910 & 232.5 & 1,822 & 2.6 \\
\hline 2000 & 71,144 & 231.4 & 234 & 0.3 \\
\hline 2001 & 71,110 & 237.0 & -34 & -0.05 \\
\hline
\end{tabular}

Source: Statistics Canada, Vital Statistics, Vol. II, Marriages and Divorces, Catalogue 84-205.

1986-1991 data from Health Reports, Health Division, Statistics Canada, 82-003s, 1996. Annual Demographic Statistics, 1997, Cat. 91-213-XB, Tables $3.1 \& 3.2$.

Annual Demographic Statistics, 1999 and 2001, Cat. 91-213-XB, Table 5.14.

The Daily, December 2, 2002; 2001 Statistics Canada web site. 
Wayne W. McVey, Jr.

With respect to Canada, it should be noted that the marked increase in divorce after 1968 may be somewhat misleading, in that the new grounds for divorce of separation made it possible to dissolve marriages without the onerous task of committing or admitting to a marital offense. In other words, many partners unwilling to commit a marital offense or perjury in order to complete the divorce process simply remained in the separated state. Prior to 1968, the more restrictive grounds for divorce proved prohibitive for many couples having marital difficulties, thus forcing unhappy partners to resolve their problems with other options, such as separation, desertion, or maintenance of the "empty shell" relationship (Goode, 1964). The official divorce statistics prior to 1969 did not reflect these types of dissolved marriages as they were still "officially" considered to be intact marriages.

\section{Methodological Observations}

In order to understand the complete magnitude of marital breakdown in Canada, there must be a determination of the number of separations in addition to the number of divorces. An understanding of the impact of new divorce legislation upon the incidence of separation and divorced can be achieved by utilizing a simplistic trend analysis of marital breakdown census data.

Examination of separation and divorce census data for 1976, 1986 and 1996 provides a "before" and "after" look at the separated population bracketing the implementation of the 1986 Divorce Act in July of 1986. The reduction in waiting period and the more equitable settlement options would likely have the effect of reducing the number of separated populations in Canada. The confounding factor may the increased popularity of cohabitation, in that separated populations may opt for this type of relationship rather than proceeding to a divorce.

The distribution of marital status data from the 1976 Census of Canada reveals that of the total population fifteen years of age and over, 4,776, 410 or 27.9 percent were single, $10,593,140$ or 61.9 percent were married, $1,043,550$ or 6.1 percent were widowed, and 302,525 or 1.7 percent were divorced. Correspondingly, the 2001 Census reported $8,139,330$ or 33.5 percent of the population over 15 years of age being single, 12,011,670 or 49.5 percent married, 1,541,905 or 6.4 percent widowed, and 1,854,760 or 7.6 percent were divorced. The separated population reported in 1976 was 380,720 or 2.2 percent and in 2001, the separated population accounted for 733,880 or 3.0 percent. When these two indicators of marital breakdown are combined into a dissolution index, the total marital breakdowns accounted for 2,345,590, or 10.7 percent 
Table 3

Percentage Distribution of Marital Status (Age 15 and Over)

Both Sexes for Canada, Alberta and Quebec: 1976 - 2001

\begin{tabular}{|c|c|c|c|c|c|c|}
\hline Marital Status & 1976 & 1981 & 1986 & 1991 & 1996 & 2001 \\
\hline \multicolumn{7}{|l|}{ Canada } \\
\hline $\begin{array}{l}\text { Single } 15 \text { and } \\
\text { over }\end{array}$ & 27.9 & 27.9 & 27.2 & 30.7 & 32.2 & 33.5 \\
\hline Married & 62.0 & 60.9 & 60.4 & 54.1 & 51.2 & 49.5 \\
\hline Widowed & 6.1 & 6.1 & 6.3 & 6.5 & 6.4 & 6.4 \\
\hline Divorced & 1.8 & 2.7 & 3.5 & 6.0 & 7.2 & 7.6 \\
\hline Separated & 2.2 & 2.5 & 2.6 & 2.8 & 3.0 & 3.0 \\
\hline $\begin{array}{l}\text { Divorced and } \\
\text { Separated }\end{array}$ & 4.0 & 5.1 & 6.1 & 8.8 & 10.2 & 10.7 \\
\hline \multicolumn{7}{|l|}{ Alberta } \\
\hline $\begin{array}{l}\text { Single } 15 \text { and } \\
\text { over }\end{array}$ & 27.4 & 28.1 & 26.8 & 30.0 & 30.6 & 32.7 \\
\hline Married & 62.9 & 61.7 & 61.7 & 55.7 & 54.0 & 51.9 \\
\hline Widowed & 5.2 & 4.7 & 4.9 & 5.1 & 5.2 & 5.0 \\
\hline Divorced & 2.5 & 3.3 & 4.2 & 6.5 & 7.4 & 7.6 \\
\hline Separated & 1.9 & 2.2 & 2.3 & 2.7 & 2.9 & 2.9 \\
\hline $\begin{array}{l}\text { Divorced and } \\
\text { Separated }\end{array}$ & 4.5 & 5.5 & 6.6 & 9.2 & 10.3 & 10.4 \\
\hline \multicolumn{7}{|l|}{ Quebec } \\
\hline $\begin{array}{l}\text { Single } 15 \text { and } \\
\text { over }\end{array}$ & 31.0 & 30.2 & 28.9 & 35.1 & 38.2 & 40.7 \\
\hline Married & 60.3 & 59.3 & 59.0 & 48.7 & 43.7 & 40.3 \\
\hline Widowed & 5.5 & 5.8 & 6.1 & 6.6 & 6.6 & 6.7 \\
\hline Divorced & 1.4 & 2.6 & 3.8 & 7.2 & 9.0 & 10.0 \\
\hline Separated & 1.8 & 2.1 & 2.2 & 2.5 & 2.5 & 2.3 \\
\hline $\begin{array}{l}\text { Divorced and } \\
\text { Separated }\end{array}$ & 3.2 & 4.7 & 6.0 & 9.6 & 11.5 & 12.4 \\
\hline
\end{tabular}

Source: Data calculations from McVey-Robinson data files.

Note: 1991, 1996 and 2001 common-law partners are classified according to their legal marital status. 
Wayne W. McVey, Jr.

(Tables 3). The number of people reporting divorced status almost tripled between 1986 and 2001 from 690,490 to $1,854,760$, increasing from 2.3 to 7.6 percent. Accordingly, the separated population increased marginally over the same period of time. This was likely due to the new changes in the 1985 divorce legislation that allowed a shorter separation period for those seeking divorce, hence accelerating the dissolution process.

Special cross-tabulations from the 1976 census concerning population by marital status, sex and age were obtained through the cooperation of the Alberta Bureau of Statistics for Canada and all provinces. Such cross-tabulations for marital status by sex and age were made available by Statistics Canada for the 1981, 1986, 1991, 1996 and 2001 census years. The marital status categories included single (never married), married, widowed, divorced, and separated. The census of Canada utilized the householder approach, whereby the respondent was responsible for providing the required information on marital status for all household members. It is important to recognize that the census schedule does not indicate whether the separated status was achieved legally (i.e., legal separation) or informally (i.e., non-legal separation). It is possible that both male and female respondents may have preferred to indicate their legal marital status as married rather than their non-legal separated status. This may contribute to the under-representation of the actual incidence of separation within the general population. For example, in 1976 this self-reporting yielded 217,425 separated females for Canada, however, only 163,295 males indicated this status.

Logically, the transition from married to separated status should produce an equal number of separated males and females. There are several possible explanation for this underreporting of males in the separated status. As noted by Ambert (1980), the separated male may live with another partner upon separation and simply declare himself as married or single in the census. It is likely that the separated female may be more inclined to recognize her true marital status than the male. The more dependent female, because of the presence of children, may have no other recourse than to seek assistance through the family court or other governmental assistance agencies. This pursuit of financial or social support would serve to crystallize the separated status for the female, as well as limit her mobility, thus making it easier for her to be located for census purposes (Ambert, 1980). In addition, one must consider the mobility potential of the separated male, in that he could escape the attention of the census through migration.

Lacking standardized summary measurement techniques for the analysis of separation and divorce patterns, simplified separation, divorce and dissolution indexes were utilized. The separation index relates the number of separated 
Is Separation still an Important Component of Marital Dissolution?

population to the total married population. The divorce index relates the divorced population to the sum of the total married and separated. The total dissolution index becomes the more sensitive measure of the population associated with marital breakdown which was obtained by combining both the divorced and separated populations and relating this sum to the total married population. For example, a total dissolution index of 6.5 indicates that the divorced and separated statuses combined account for 6.5 percent of the total married population in Canada as reported in the 1976 census. This dissolution index increased to 21.6 in the 2001 Census of Canada.

There are two distinct analytical methodological approaches that can be utilized in the study of marital dissolution. The cohort approach permits the longitudinal analysis of marital disruption by a group of couples (or individuals) married during a specific calendar year. Correspondingly, the marital history or events experienced by this marriage cohort is monitored over a specified interval of time. The second approach employs data specific to a given time period. This period approach permits the analysis of the pattern of divorce and separation at a fixed moment in time, or in this case, several fixed moments in time. The crosssectional census data for 1976, 1986, 1996 and 2001 utilized in this research is amenable to the period approach. It is important to recognize that the measures for the four census periods will reveal changing patterns in terms of separation, divorce and the total dissolution indexes.

\section{Research Findings}

It is appropriate to review the general patterns of marital dissolution for the four study periods - 1976, 1986, 1996 and 2001 - for Canada as a whole. The now married status dominates throughout the 1976 to 2001 period, however, reflecting a consistent decline over the study period. As shown in Table 3, the proportion of the population now married for Canada steadily declined from 62.0 per cent in 1976 to 49.5 percent in 2001. This decline in the married population was evident in both Alberta and Quebec, however Quebec showed the more significant decline from 60.3 per cent in 1976 to a low of 40.3 per cent in 2001. This likely reflects the greater impact of cohabitation in Quebec coupled with the slightly higher divorce rate.

Dramatic increases in all three measures over the study period are revealed for every age group in Tables $4-6$. While the total dissolution index increased over the entire study period, the greatest growth was from 3.5 to 37.5 for the 1519 age group.. The general growth pattern revealed for all measures from 1976 to 2001 was magnified by the introduction of the 1985 divorce legislation that was implemented in mid-1986. With the more equitable settlements and shorter 
Wayne W. McVey, Jr.

required separation time, the separated population who previously had to wait for several years for a divorce could now move swiftly to complete the divorce process, hence, not lingering in the separated status for any length of time. Accordingly, the separation index trend over the study period for Canada did not reveal a similar growth pattern.

Modest declines in the indices are noted for the younger ages 20-34 between 1996 and 2001. These declines may be the result of the increasing popularity of cohabitation among the younger populations, thus reducing the risk of separation and divorce if they elected to marry instead of cohabit.

The most significant pattern revealed in an earlier study was that the proportion separated exceeded the proportion divorced for every age category adding substantially to the total dissolution index (McVey \& Robinson, 1981). By 2001, this pattern had completely reversed, in that the proportion divorced now exceeds the proportion separated in every age category.

Figures $2-4$ reveal the age patterns of the divorce, separation and total dissolution index for Canada, Alberta and Quebec from the 2001 Census of Canada. The divorce index rises from age 25-29 reaching a high at ages 50-54 for both provinces and Canada with Quebec having a considerably higher index for these age groups. Similar patterns are shown in Figure 3 for the separation index, however Quebec had a lower index for these age groups, however the separation index increased for this province in the later ages. The total dissolution index was highest for Quebec in every age group except for age groups over 80 years.

In contrast to earlier census years, the 2001 separation index for Canada was lower than 10.0 for all ages with the exception of the 15-19 age group (Figure 5). While the contribution of separation to the total dissolution index is not as significant as it was prior the enactment of the 1985 Divorce Act, this type of marital breakdown must be taken in to account for any realistic assessment of total marital dissolution. A true assessment of total marital and non-marital partnerships, as well as dissolution will require a complete reporting of cohabitation separations. 
Is Separation still an Important Component of Marital Dissolution?

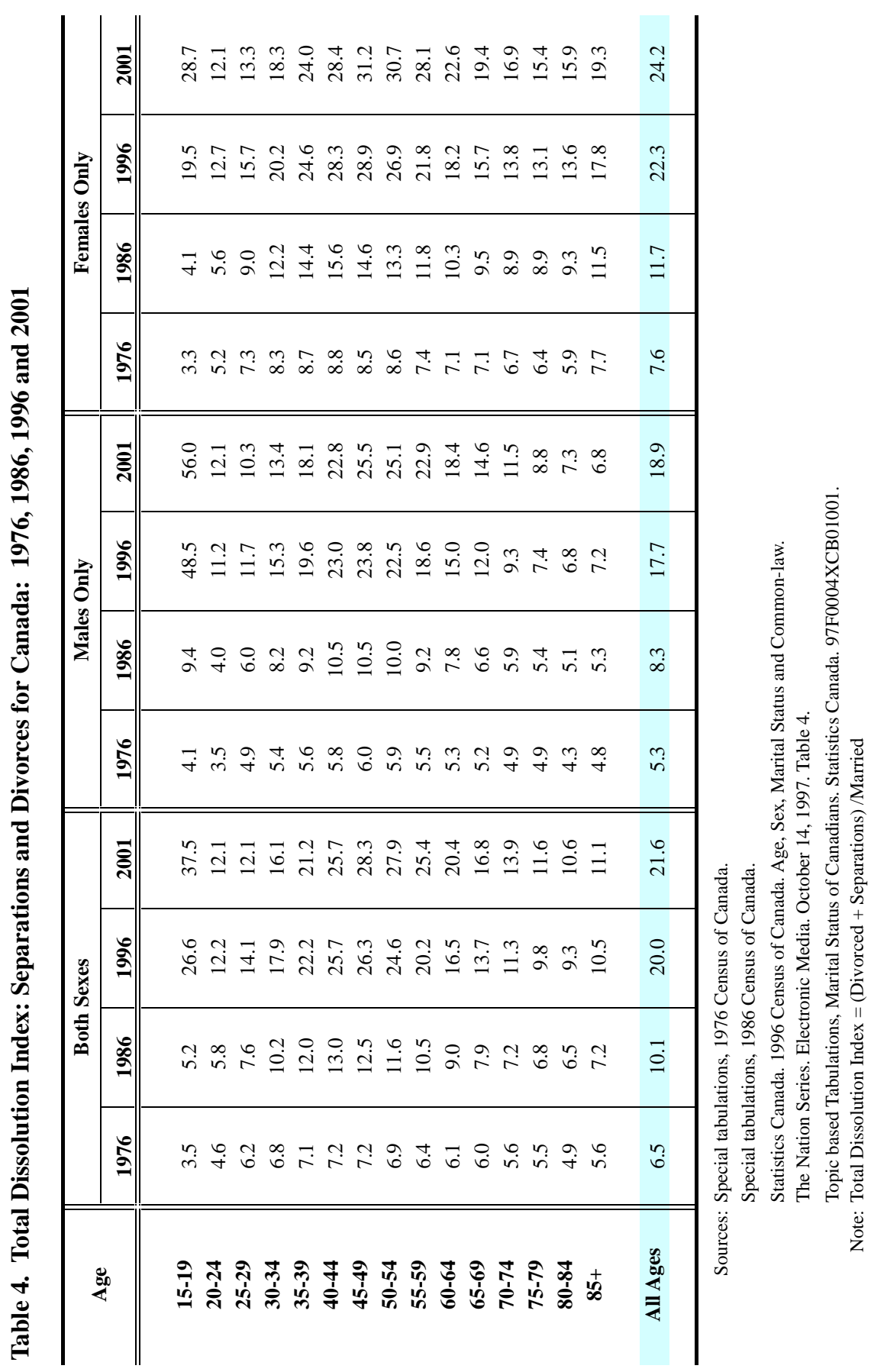


Wayne W. McVey, Jr.

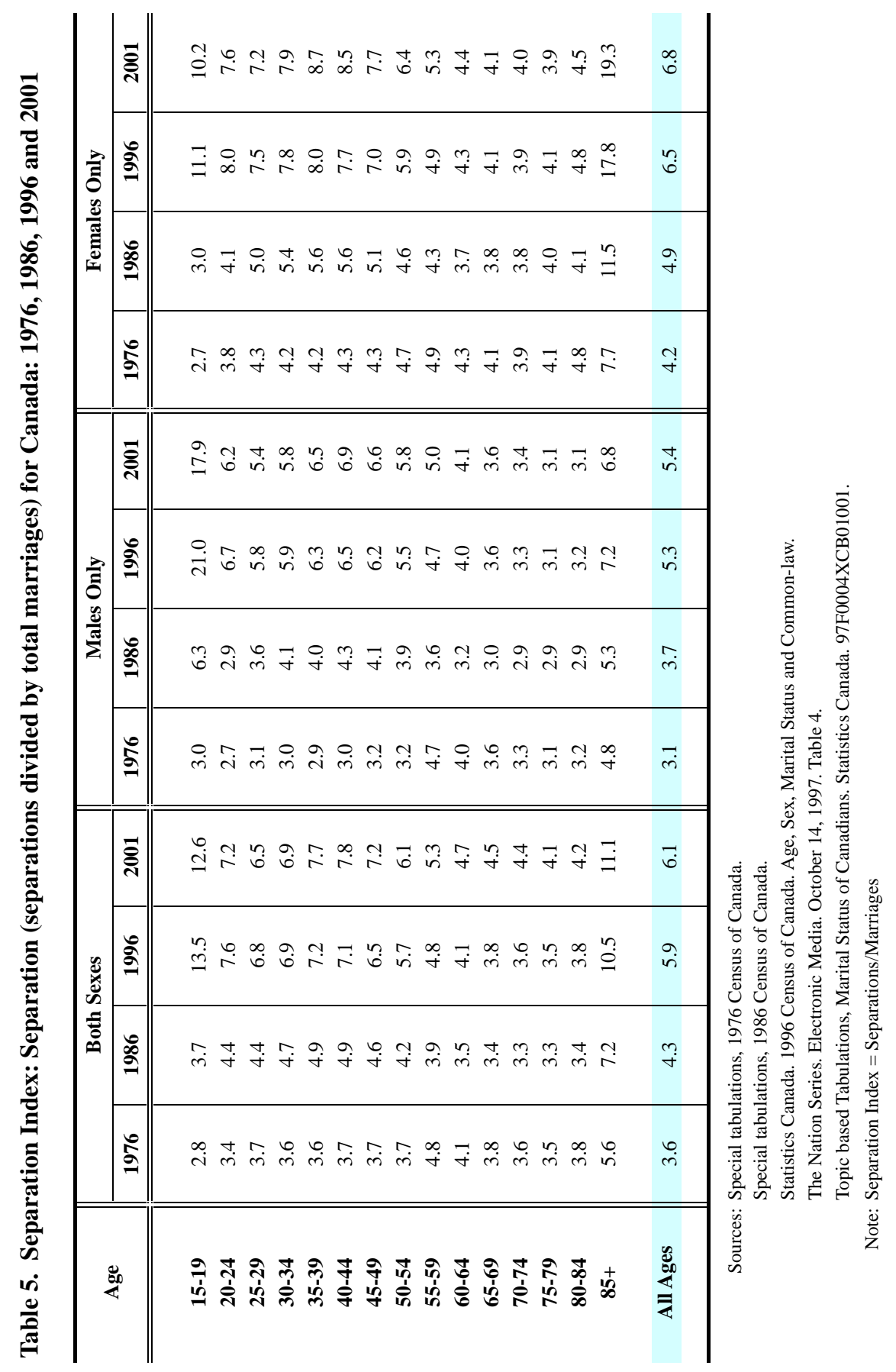


Is Separation still an Important Component of Marital Dissolution?

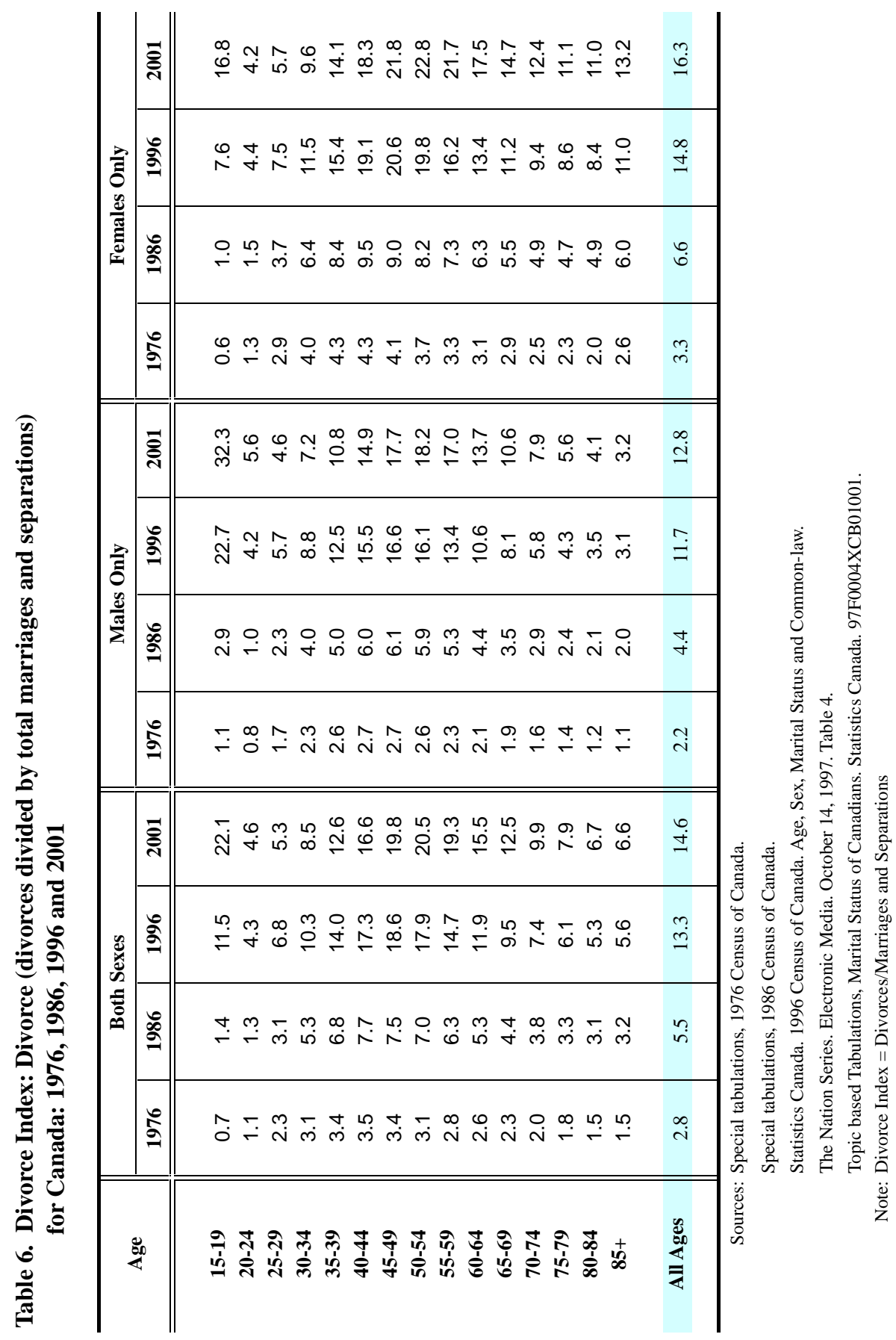


Wayne W. McVey, Jr.

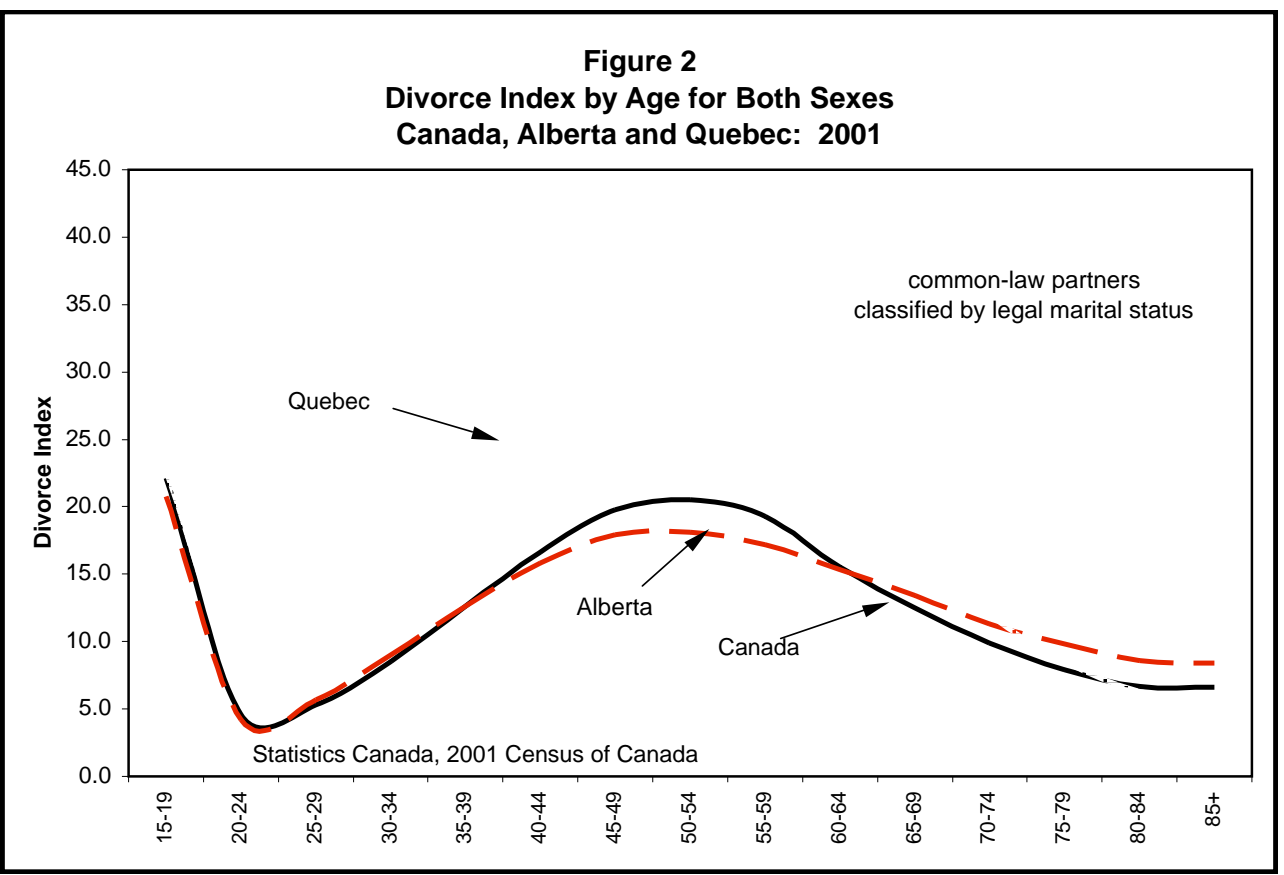

Figure 3

Separation Index by Age for Both Sexes

Canada, Alberta and Quebec: 2001

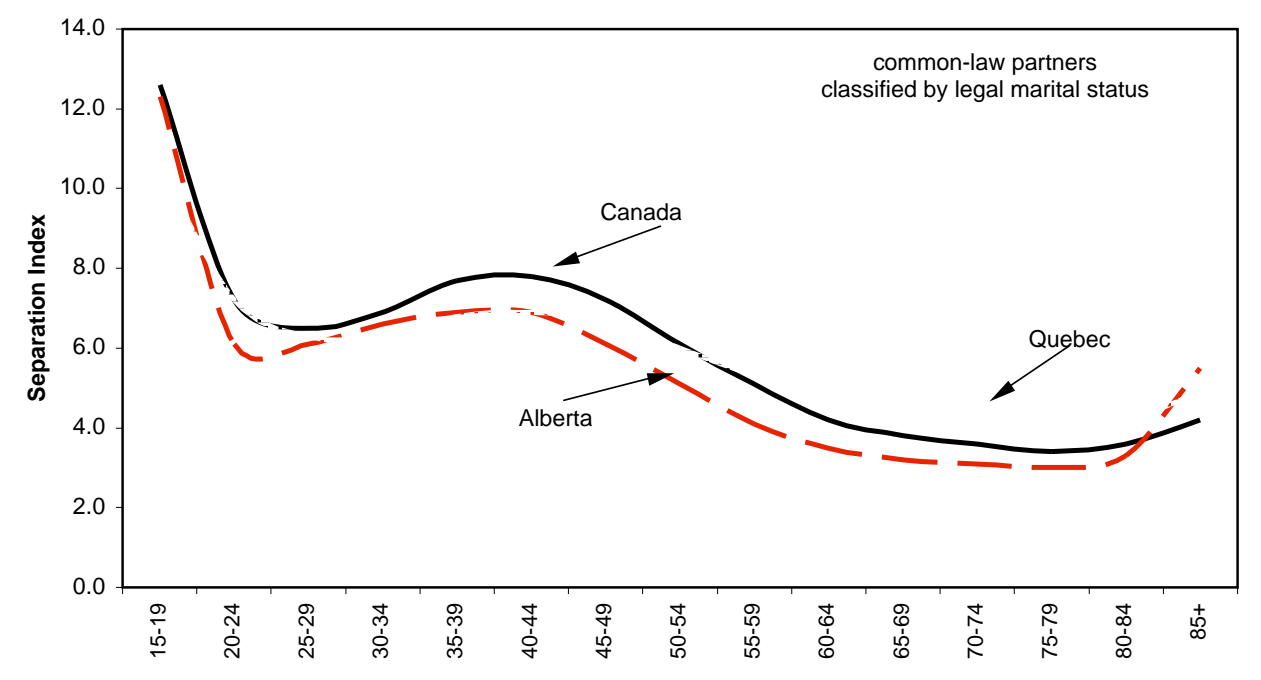


Is Separation still an Important Component of Marital Dissolution?

Figure 4

Total Dissolution Index by Age for Both Sexes

Canada, Alberta and Quebec: 2001

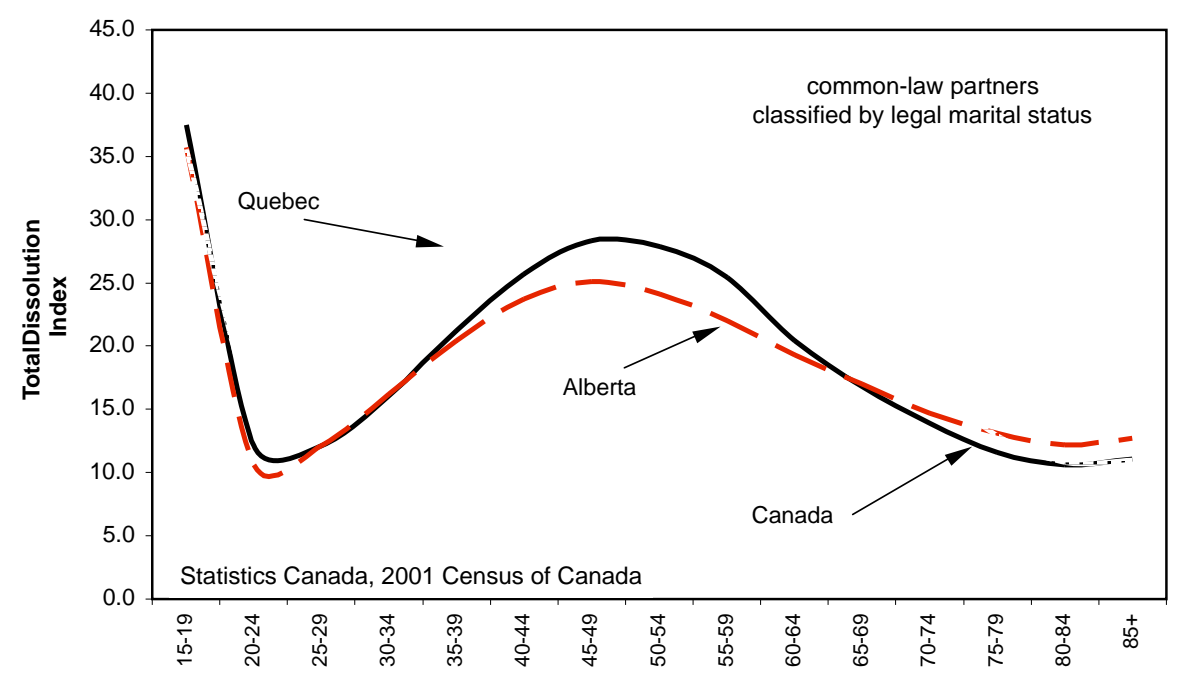

Figure 5

Divorce, Separation and Total Dissolution Indices by Age for Both Sexes, Canada: 2001

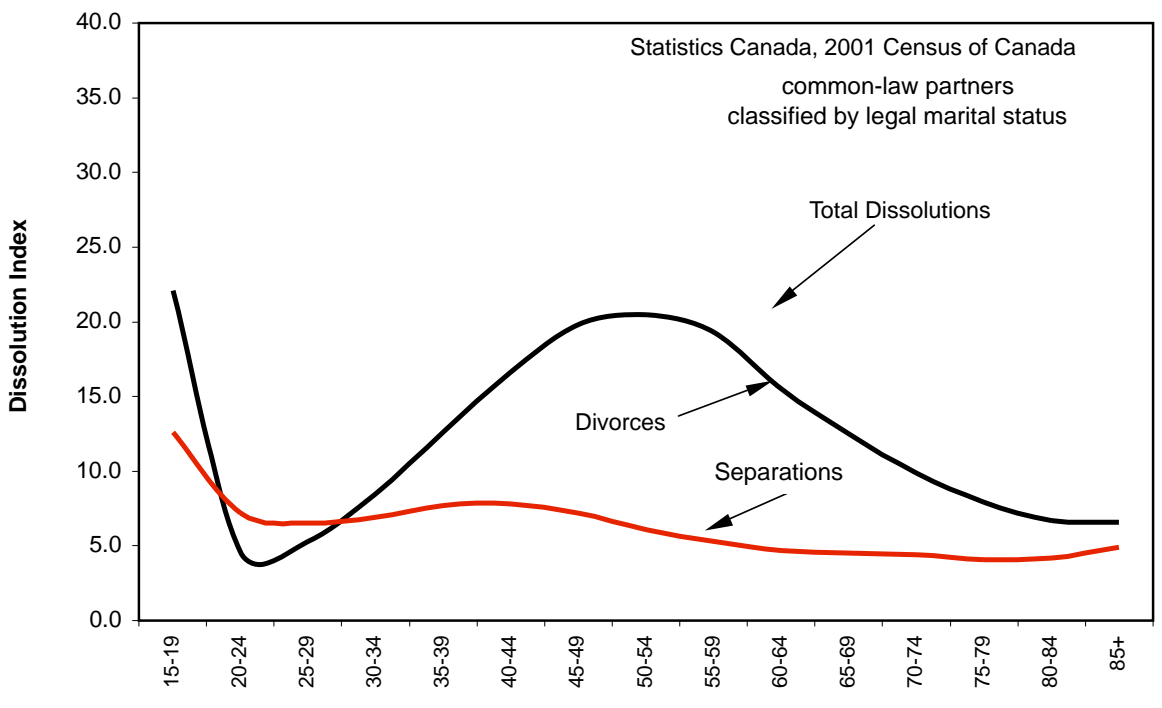


Wayne W. McVey, Jr.

\section{References:}

Ambert, Anne-Marie, 1980. Divorce in Canada. Don Mills, Ontario: Longman Canada Ltd

Booth, Alan and Lynn White, 1977. “Thinking about Divorce.” Journal of Divorce 1:7-19.

Cherlin, Andrew J., 1992. Marriage, Divorce, Remarriage. Cambridge, Massachusetts: Harvard University Press.

Dumas, Jean and Yves Peron, 1993. Marriage and Conjugal Life in Canada. Current Demographic Analysis. Catalogue 92-534E Occasional. Ottawa: Minister of Industry, Science and Technology.

Eichler, Margrit, 1988. Families in Canada Today: Recent Changes and their Policy Implications. Second Edition. Toronto: Gage Publishing Ltd.

Goode, William J., 1964. The Family. Englewood Cliffs, N.J.: Prentice Hall, Inc.

Ishwaran, K., (Ed.), 1983. Marriage and Divorce in Canada. Toronto: Methuen Publications.

McKie, D. C., Prentice, B. and P. Reed, 1983. Divorce: Law and the Family in Canada. Cat. No. 89-502E. Ottawa: Statistics Canada.

McVey, Wayne W., Jr. and Warren E. Kalbach, 1995. Canadian Population. Scarborough, Ontario: Nelson Canada. See Chapter 8, Nuptiality and the Family, pp. 216-262.

McVey, Wayne W. Jr., and Barrie W. Robinson, 1981. "Separation in Canada: New Insights concerning Marital Dissolution." Canadian Journal of Sociology 6.3: 353-366.

Ram, Bali, 1990. New Trends in the Family. Cat. No. 91-535E Occasional. Ottawa: Statistics Canada.

Statistics Canada, 2001. Demographic Situation in Canada 2000. Cat. No. 91209-XPE Annual.. Prepared by Alain Bélanger, Yves Carrier and Stephane Gilbert. Ottawa: Statistics Canada, June. 
Is Separation still an Important Component of Marital Dissolution?

Statistics Canada, 1998. Report on the Demographic Situation in Canada 1997.

Cat. No. 91-209-XPE Annual. Prepared by Alain Bélanger and Jean Dumas.

Ottawa: Statistics Canada, June.

Statistics Canada, 1997. Report on the Demographic Situation in Canada 1996. Cat.

No. 91-209-XPE Annual. Prepared by Jean Dumas and Alain Bélanger. Ottawa:

Statistics Canada, January.

Sweet, James A. and Larry L. Bumpass, 1987. American Families and

Households. New York: Russell Sage Foundation.

Weiss, Robert S., 1975. Marital Separation. New York: Basic Books, Inc.

Wu, Zheng, 2000. Cohabitation: An Alternative Form of Family

Living. Don Mills, Ontario: Oxford University Press. 